\title{
Hydrogeophysical Investigation and Aquifer Evaluation of the Formations in Nsukka Area, Southeastern Nigeria
}

\author{
Emmanuel Ezim ${ }^{*} \quad$ Izuchukwu Obiadi ${ }^{2}$ \\ 1.Department of Geology, University of Ibadan, Ibadan, Nigeria \\ 2.Geological Science Department, Nnamdi Azikiwe University, Awka, Nigeria
}

\begin{abstract}
The study targeted the aquiferous Ajali Sandstone and Nsukka Formations that underlies the Nsukka metropolis and its environs (within Latitudes $6^{\circ} 80^{1} \mathrm{~N}$ and $6^{\circ} 89^{1} \mathrm{~N}$; Longitudes $7^{\circ} 21^{1} \mathrm{E}$ and $7^{\circ} 30^{1} \mathrm{E}$ ), covering an area of about 210 square kilometres. Thirty four (34) cross array Vertical Electrical Sounding (using the Schlumberger electrode configuration) and records from four (4) selected boreholes have been used to investigate the subsurface distribution of electrical resistivity and to delineate hydraulic properties of aquifers in Nsukka area, Southeastern, Nigeria.The electrical surveys of the area show high values of permeability, ranging from 0.0075 to $0.015 \mathrm{~cm}^{2}$, hydraulic conductivity, ranging from 8.29 to $16.64 \mathrm{~m} / \mathrm{s}$, transmissivity, between 455.87 and $1002.48 \mathrm{~m}^{2} \mathrm{~s}^{-1}$, and specific yield, ranging from 2.35 to $4.76 \mathrm{~m}^{3}$. A tie with the results of borehole logs analysis reveals the presence of at least four layers of contrasting hydraulic conductivity. Analyses, however, suggests that the Nsukka Formation (which overlies the Ajali Sandstone) is thick and poorly conductive while the Ajali Sandstone unit is homogenous and anisotropic and has higher conductivity (especially beyond the depth of 100 $\mathrm{m})$, suggesting a prolific water-bearing formation at such depth and beyond. The Ajali Sandstone aquifer in the area is thick and prolific. The distribution of major geological units, well log data, static water level data were shown to have influence on the groundwater occurrence and flow pattern in the area.
\end{abstract}

Keywords: Ajali Sandstone Aquifer, Nsukka Metropolis, Resistivity measurements, Well data

DOI: $10.7176 / \mathrm{JEES} / 11-7-04$

Publication date:July $31^{\text {st }} 2021$

\section{Introduction}

The Nsukka area, southeastern Nigeria has little or no surface water, resulting to some water resources problem and to high dependent of groundwater. The area included the University of Nigeria community, Nsukka town and environs, in Enugu State, Southeastern Nigeria. The area lies within Latitude $6^{\circ} 80^{1} \mathrm{~N}$ and $6^{\circ} 89^{1} \mathrm{~N}$, and Longitudes $7^{\circ} 21^{1} \mathrm{E}$ and $7^{\circ} 30^{1} \mathrm{E}$ and covers an area of about $210 \mathrm{~km}^{2}$ (Figure 1). The geology is predominantly the Ajali Formation, overlain by thick Nsukka Formation that has high infiltration capability (Ezim et al., 2016; Nwajide, and Reijers, 1996).

Mamah and Ekine (1989) had conducted a geo-electrical survey on the Nsukka Formation and distinguished two to three layers of the basal sandstone within the formation. Mamah (1997), suggested with the aid of the resistivity sounding survey data carried out at Orba for the UNDP, that the depth to water table in the area is about $95 \mathrm{~m}$ and that the aquifer is the Ajali Sandstone. The characteristics of this aquifer with respect to well yield remain uncertain, as most boreholes and hand dug wells in the area turn abortive. The need for adequate water supply in the Nsukka area necessitated the use of vertical electrical sounding to evaluate the hydrogeological potential of the Ajali Sandstone.

\subsection{Geology of the Study Area}

The Nsukka area, geologically, lies within the Anambra Basin. The Anambra Basin is an inland sedimentary basin sandwiched between the Southwestern part of the Benue Trough and the Petroliferous Niger Delta. The origin, sedimentology and stratigraphy of the basin have been well presented by several authors: Agagu et al. (1985), Benkhelil (1987), Kogbe, (1989b), Murat, (1972) and Nwajide, (2006a). The basin is bounded in the west by the Precambrian Basement Complex, of western Nigeria, and in the east by the Abakaliki Anticlinorium. The Southern boundary is at Onitsha which coincides with the northern boundary of the Niger Delta Basin, while the northern boundary is taken to correspond to the limit of the exposure of the Maastrichtian sediments Nwajide, (2006a and b). The basin is exposed over a roughly triangular territory estimated at some $95,000 \mathrm{~km}^{2}$. It rests on the Awgu Formation of the southern Benue Trough (in an angular unconformity relationship), but underlies the Niger Delta for a considerable extent. The total area is possibly in excess of $140,000 \mathrm{~km}^{2}$. 


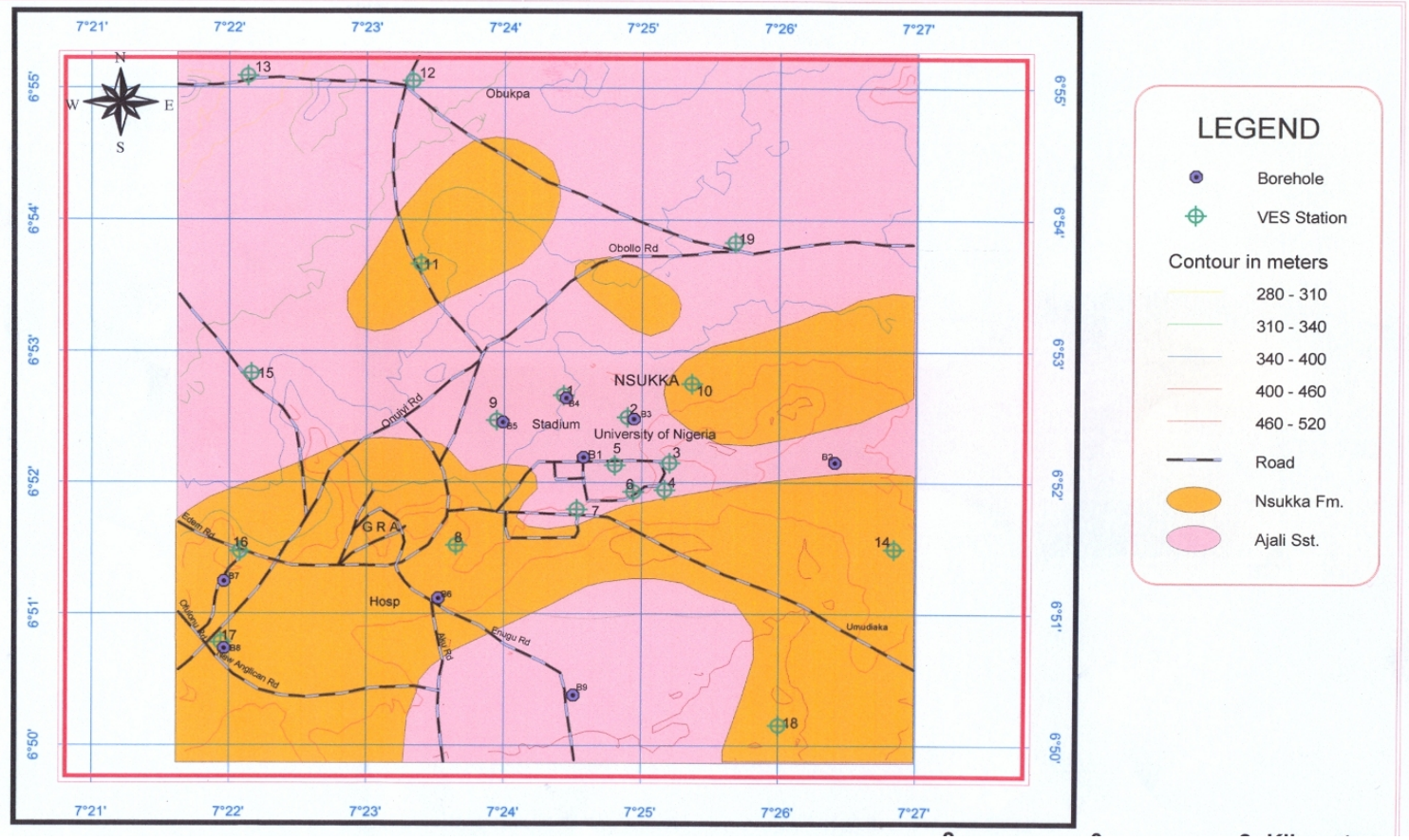

Figure 1. Geological map of the study area showing accessibility, sounding stations and borehole locations

Amongst the sediments of the basin are the Mamu, Nsukka and Ajali Sandstone Formations. Slow subsidence followed by a major regression led to the deposition of the Mamu (coal-bearing) and Ajali Formations which accumulated during the Maastrichtian Epoch. The Mamu Formation most probably documents a delta strand plain which resulted in coal seams in addition to delta sand bars and Chenier ridges. The overlying Ajali Sandstone has been attributed to fluvial deposition, and the development of shallow marine sub tidal sand bars ${ }^{16}$. The Danian Epoch of the Palaeocene period saw the deposition of the Nsukka Formation. Sedimentation was mainly of fluvial origin (Table 1) (Nwajide 2006a; Nwajide, and Reijers, 1996). The borehole data in the southern parts of the Anambra Basin used in the reconstruction of the stratigraphic unit reveals that the formations (i.e. Nsukka, Ajali and Mamu Formations) all appear to be steeply inclined and dipping towards the western flank of Onitsha High, and flattening out below the Imo Formation, (see Figure 2).

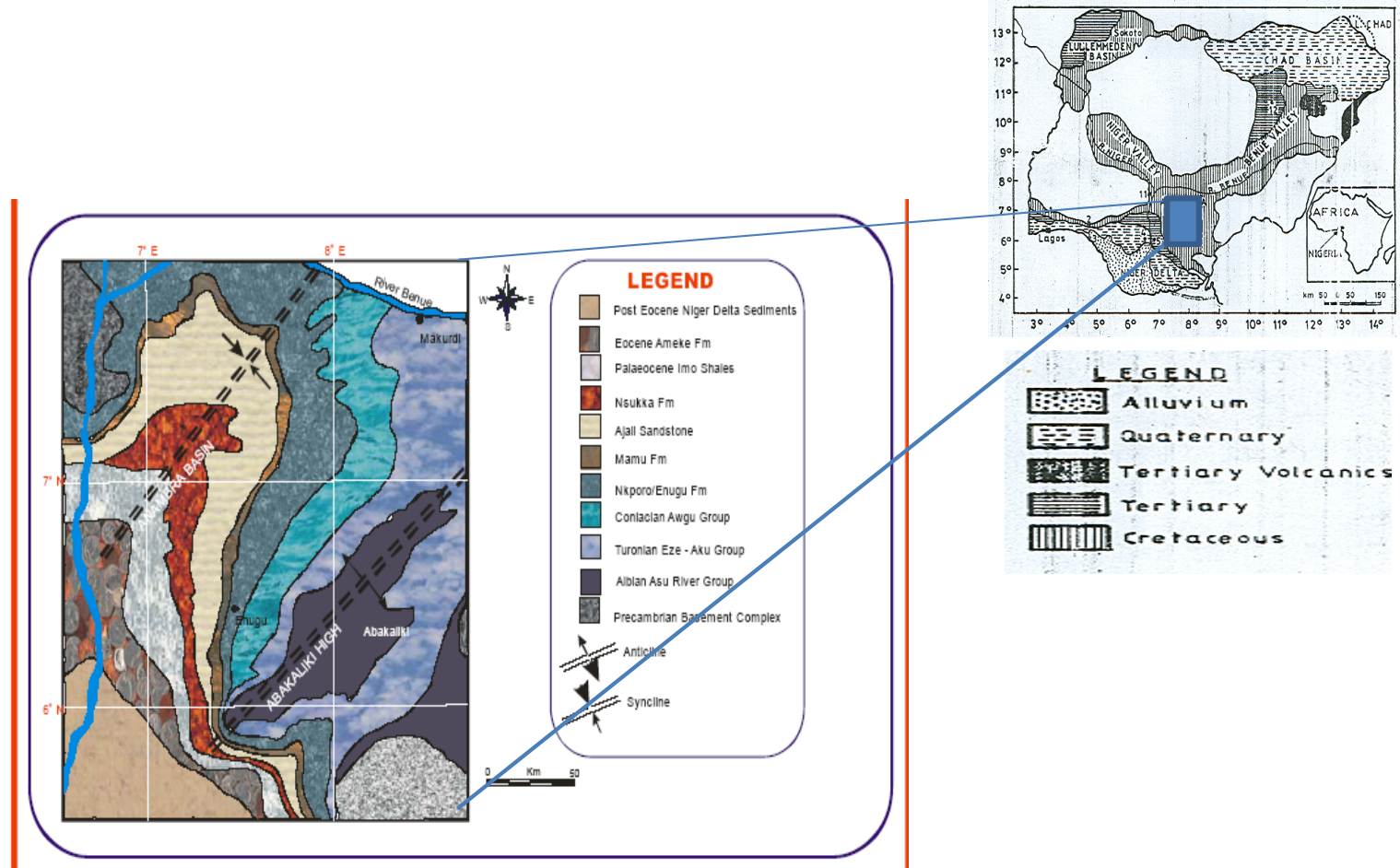

Figure 2. Geological map of Southeastern Nigeria showing the Southern Benue Trough and Anambra Basin, (Modified after Burke et al., 1972, Kogbe, 1989b, and Nwajide, 2006a) 
Table 1. Lithostratigraphic Units of the Anambra Basin (Modified from Nwajide 2006a)

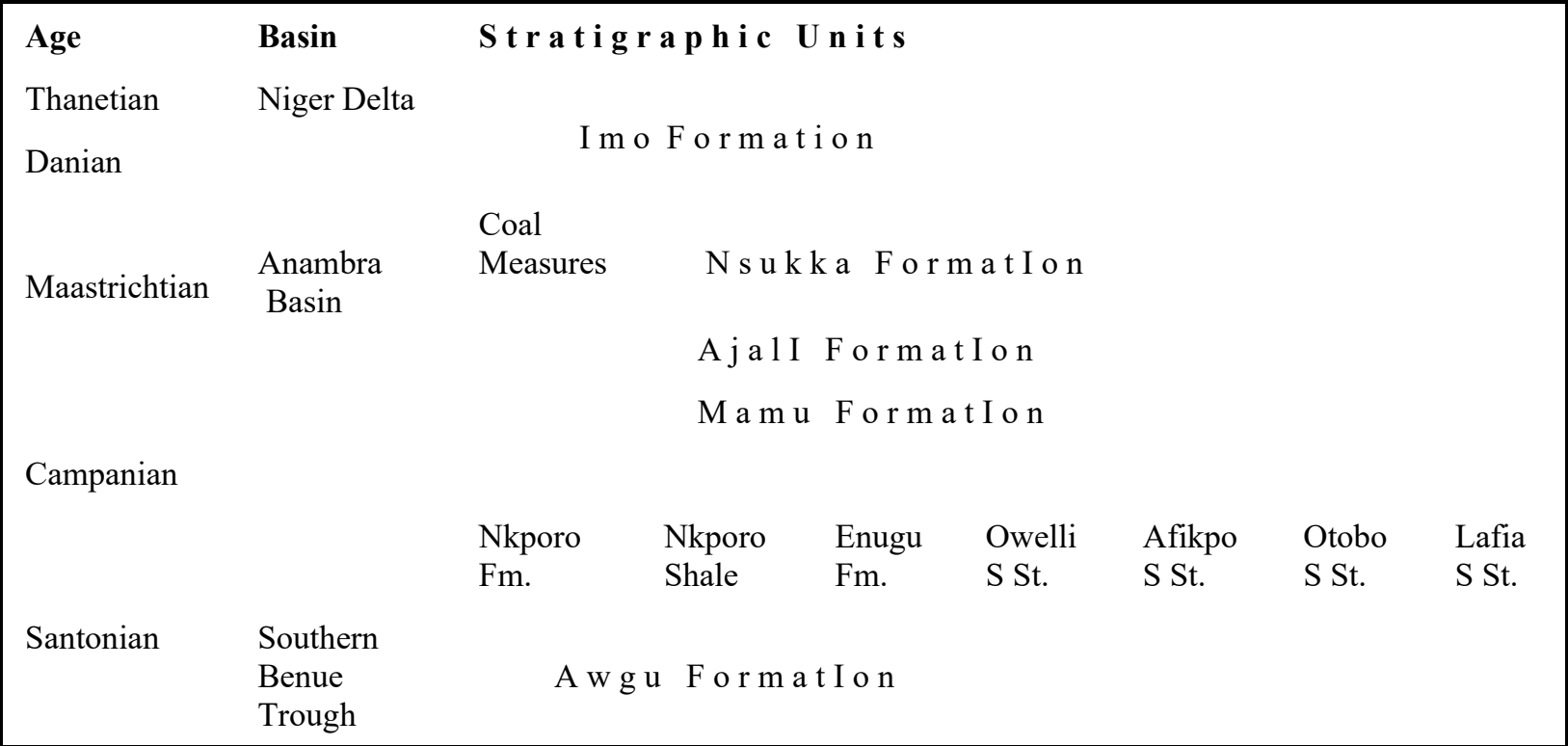

The Ajali Formation consists of thick friable, poorly sorted sandstone typically white in colour but sometimes Iron-stained. Marked bandings of coarse and fine layers are displayed. The sand grains and large fragments are sub-angular, with a sparse cement of white clay. Large-scale, cross bedding is also one of its characteristic features (Banerjee, 1979; Kogbe, 1989b). Erosion surfaces within successions of the Ajali Sandstone are poorly defined but can be identified either by the presence of a laterally persistent granular bed usually a few centimetres thick or the abrupt truncation of burrowed horizons. The Ajali Formation is well displayed along the lowland and dry valley zones of the study area including: Obukpa, Onuiyi Road, Ibagwa Road, Obollo Road, Base of the Physics observatory, Odim area, Franco and beyond Zik's flat (Figure 1). The thickness of the Ajali Formation has been measured by several workers. According to Nwajide (2006a), maximum recorded thickness was from the Igbariam borehole where the formation is up to $534 \mathrm{~m}$ thick. This thickness decreases gradually towards the west and east to only a few tens of metres around Okigwe.

The depositional environment of the Ajali Sandstone as described by some authors include; a fluvio-deltaic depositional environment (Agagu et al., 1985; Burke et al., 1972), an inert tidal bar and channel system (Banerjee, 1979), an inter-tidal flat, based strictly on its sedimentary facies characteristics (Amajor, 1984). The lateritic Nsukka Formation consists of an alternating succession of sandstone, dark shale, sandy shale, thin coalseams at various horizons and thin beds of limestone towards the top (Kogbe, 1989b; Murat, 1972; and Nwajide, 2006b). The beds are generally gently dipping (amount of dip ranging from $1^{\circ}$ to $6^{\circ}$ ). The lithology of the Nsukka Formation is similar to that of the Mamu Formation.

\subsection{Hydrogeology of the Study Area}

According to Onwuemesi (1990), the Ajali Sandstone aquifer is essentially unconfined and results of geo-electric resistivity surveys and static water level measurements in the relatively shallow boreholes near the crest of the escarpment indicate that the water table lies at a depth of about $55 \mathrm{~m}$. The saturated thickness of the aquifer is about $85 \mathrm{~m}$. Although the Ajali Sandstone Formation shows a wide textural variation across its thickness, borehole data show that below the water table the texture is relatively more homogenous and ranges only from fine to medium grain. Thus, within its saturated thickness, the hydraulic conductivity could range from $10^{-5}$ to $10^{-4} \mathrm{~m} / \mathrm{s}$. Values ranging from $7 \times 10^{-5}$ to $2 \times 10^{-3} \mathrm{~m} / \mathrm{s}$ were obtained by Onwuemesi (1990), and Uma, et al. (1989), using grain size data. It would appear however, that the upper limits of this range reflects the gravely and coarse sand units which predominate in the region above water table.

\section{Materials and Methods}

2.1 Field work and Vertical Electrical Sounding (VES)

Different stages of field investigations were carried out and maps produced on a scale of 1:250,000. This was followed up by fourteen (14) sets of Vertical Electrical Sounding (VES) using the Schlumberger electrode configuration. One of the advantages of this configuration lies in the fact that only two electrodes are moved at once, hence it is less inconvenient, and requires lesser crew unlike the Wenner spread (Habberjam and Watkins, 1967; Telford et al., 1990). The positions and the elevations of the sampling points and VES locations were determined with the base map and Global Positioning System (GPS) device. The resistivity Surveys (VES) were 
carried out with ABEM Terrameter (SAS 300B and SAS 1000). The ABEM Terrameter Signal Averaging System basically consists of a transmitter and receiver. The system automatically calculates the ratio of the potential difference across the layer and the current passing through the layer (V/I) and then displays it in digital form in kilo ohms, ohms or in milli-ohms.

Some precautions were taken during the field surveys in order to generate an accurate or near accurate data. For example; the electrodes were hammered firmly into the ground to at least a depth of $35 \mathrm{~cm}$ in order to avoid error reading and achieve good electrical contacts with the ground, water was poured at the point of electrode contact with the ground to possibly enhance ionic flow of current and measurements were avoided during rain and thunder-storms since they are capable of inducing hundreds of volts in long cable layout and this can cause damage to the equipment and can as well constitute risk to the crew.

Also, positions of the electrodes were kept far away from power-lines and other lateral near surface inhomogeneities, to avoid altering the value of the potential difference.

\subsection{Borehole Data acquisition}

The Rotary method was employed in the drilling all the boreholes used this study. 15 inches bit was used in the entire drilling programme. The borehole loggings carried out were limited to SP and resistivity. While the SP probed the voltage developed as a response to electrochemical effects of differences in borehole fluid and oxygen reduction of minerals, the resistivity logging measured the electrical resistivity of soil, rock, and pore fluids ${ }^{21}$. Both were run in uncased condition. The static water level, hydraulic conductivity (K), transmissivity (T) and discharge (Q) were calculated following methods described by Ezim et al. (2017), Harleman, et al. (1963), Hazen (1983), Henriet (1976), Uma, et al. (1989).

\section{Results and Discussions}

\subsection{Borehole depths and static water levels}

The summary of the results of the aquifer characterisation is presented in Tables 2, 3 and 4, while the selected borehole logs are presented in Figures 3, 4, 5 and 6. The results indicate that the borehole at the Abuja Building (A02), Franco Refactory (F03) and the Energy Centre (E04) [University of Nigeria, Nsukka (UNN)] all penetrated the Ajali Sandstone aquifer; with respective depths up to $720 \mathrm{ft}(220 \mathrm{~m}), 670 \mathrm{fts}(210 \mathrm{~m})$ and $682 \mathrm{fts}$ $(208 \mathrm{~m})$. Also, static water levels were determined and they fall within the range of 500-550 ft, 350-400ft, and $485 \mathrm{ft}$ respectively (Figures 3 to 5 ).

Similarly, the Bore hole (Z05) at ZENITH BANK (along Enugu Road, Nsukka), was drilled to a depth of $656 \mathrm{ft}$ (approximately $200 \mathrm{~m}$ ), penetrated the Ajali Sandstone aquifer as well and having a static water level determined to be in the range of 580 to $600 \mathrm{ft}$ (Figure 6).

Table 2. Average Hydraulic Conductivity (K) of earth Materials from the selected boreholes

\begin{tabular}{|c|c|c|c|c|c|c|}
\hline \multirow[t]{4}{*}{ S/No. } & \multirow{4}{*}{$\begin{array}{l}\text { Borehole } \\
\text { Location }\end{array}$} & \multirow{4}{*}{$\begin{array}{l}\text { Average } \\
d_{10^{2}}\end{array}$} & \multicolumn{3}{|c|}{$C d_{10^{2}}\left(\mathrm{~cm}^{2}\right)$} & \multirow{4}{*}{$\begin{array}{l}\text { Uma et al., } \\
(1988) \\
\mathrm{C}=6.1\end{array}$} \\
\hline & & & Harleman & Hazen (1893) & Kozeny Carman & \\
\hline & & & al. (1963) & $\mathrm{C}=100$ & in Bear (1972) & \\
\hline & & & $C=6.54 \times 10^{-4}$ & & $\mathrm{C}=64.1$ & \\
\hline 1 & Abuja 2 well & 0.002332 & $1.62 \times 10^{-6}$ & 0.2332 & 0.1494812 & 0.0142252 \\
\hline 2 & Franco 3 well & 0.001234 & $1.525 \times 10^{-6}$ & 0.1234 & 0.0790994 & 0.0075274 \\
\hline 3 & Zenith 5 well & 0.002478 & $8.07 \times 10^{-7}$ & 0.2478 & 0.1588398 & 0.0151158 \\
\hline
\end{tabular}




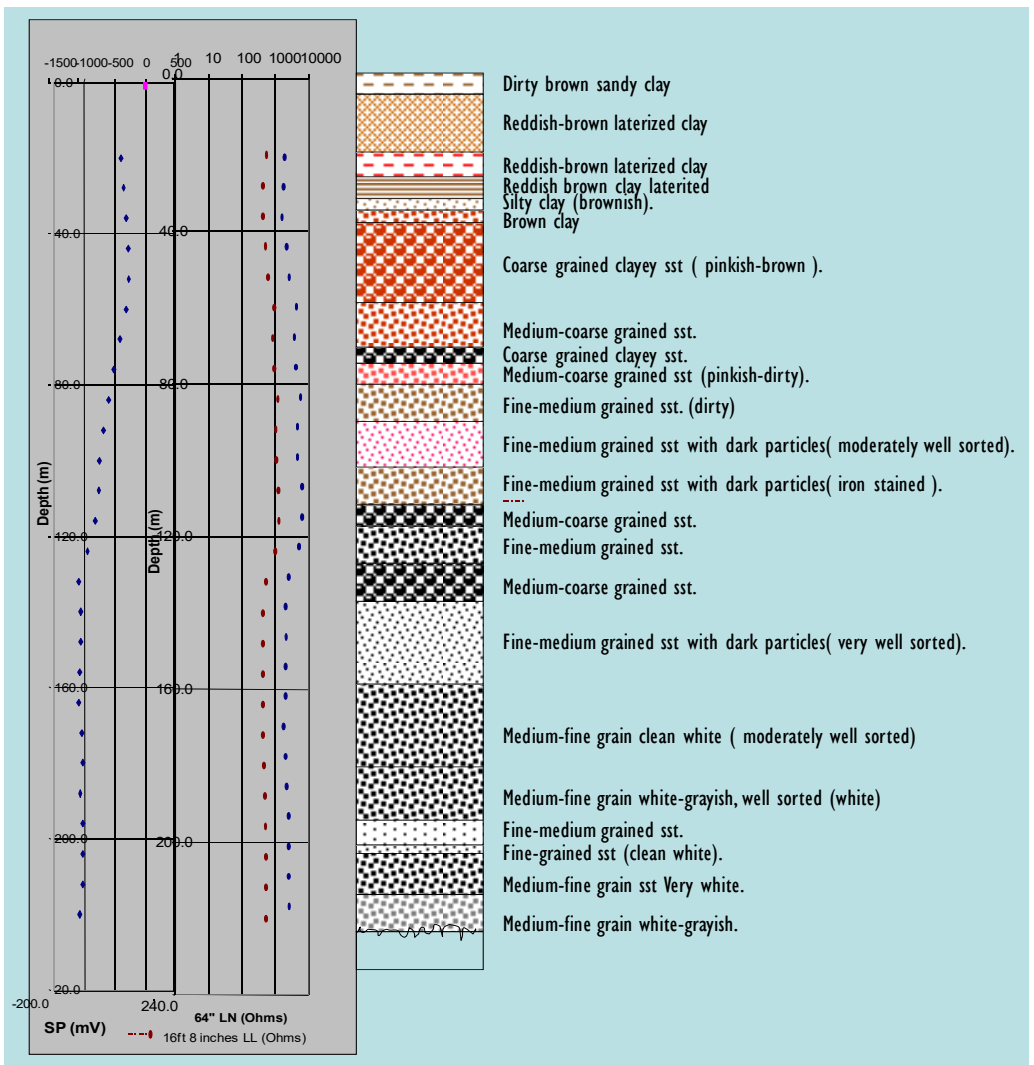

Figure 3. Log and lithological results of the borehole (A02) at Abuja Building, University of Nigeria, Nsukka

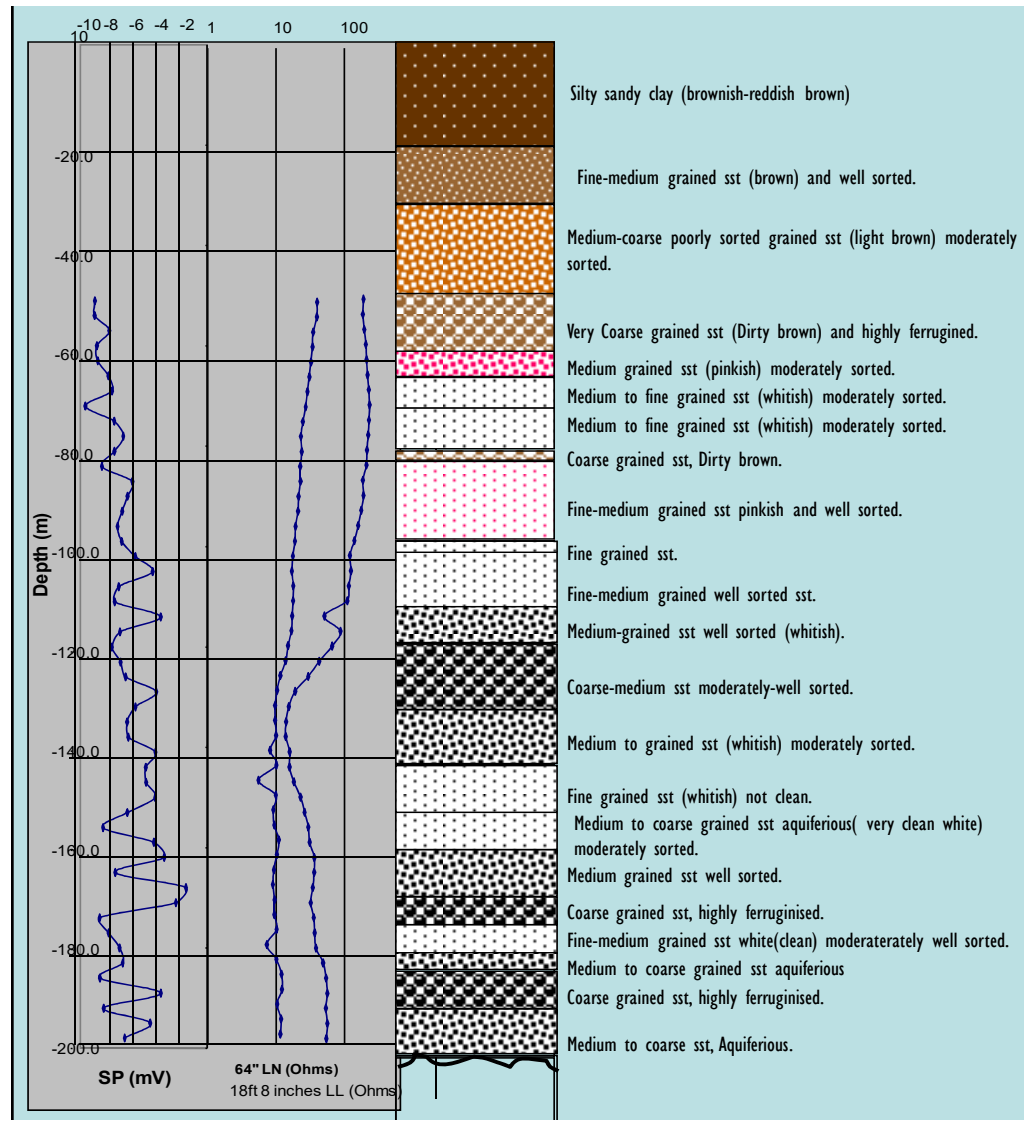

Figure 4. Log and lithological results of the borehole (F03) opposite Franco, University of Nigeria, Nsukka 


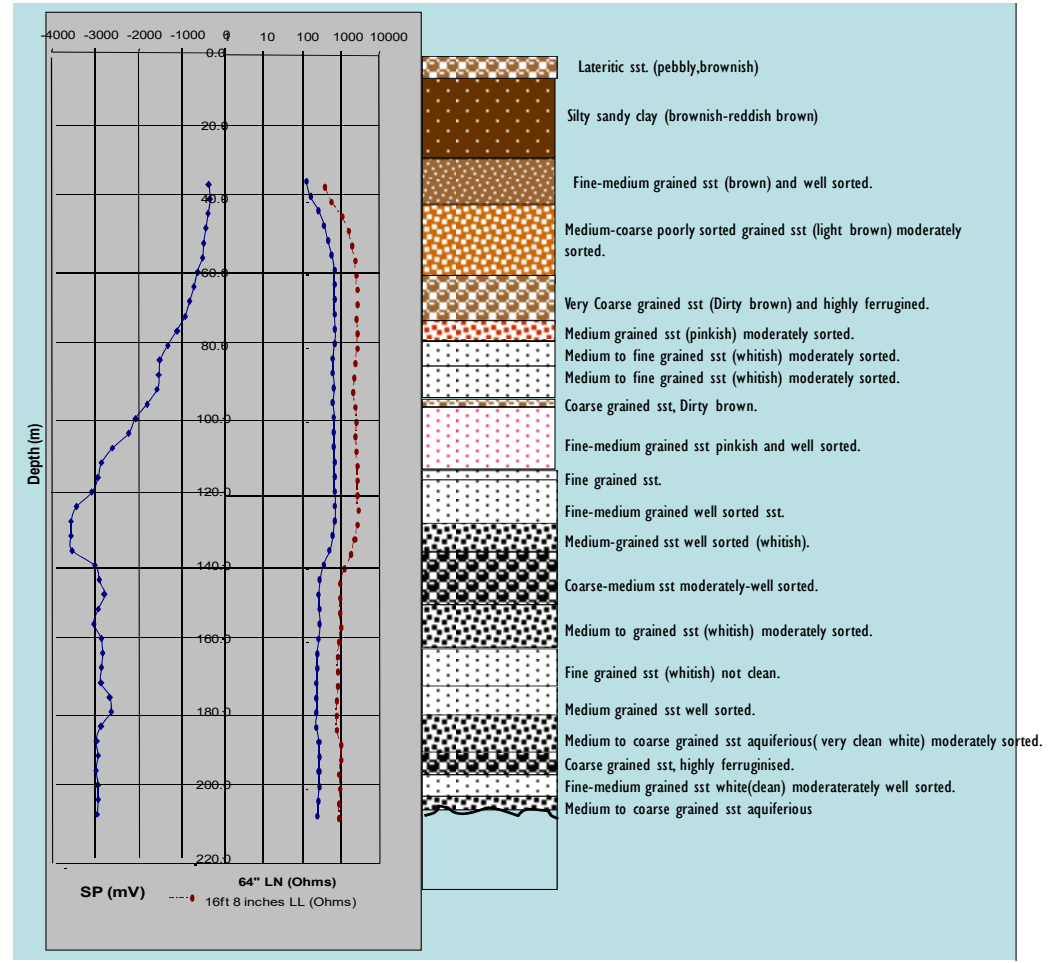

Figure 5. Log and lithological results of the borehole (E04), at the Energy Centre, University of Nigeria, Nsukka

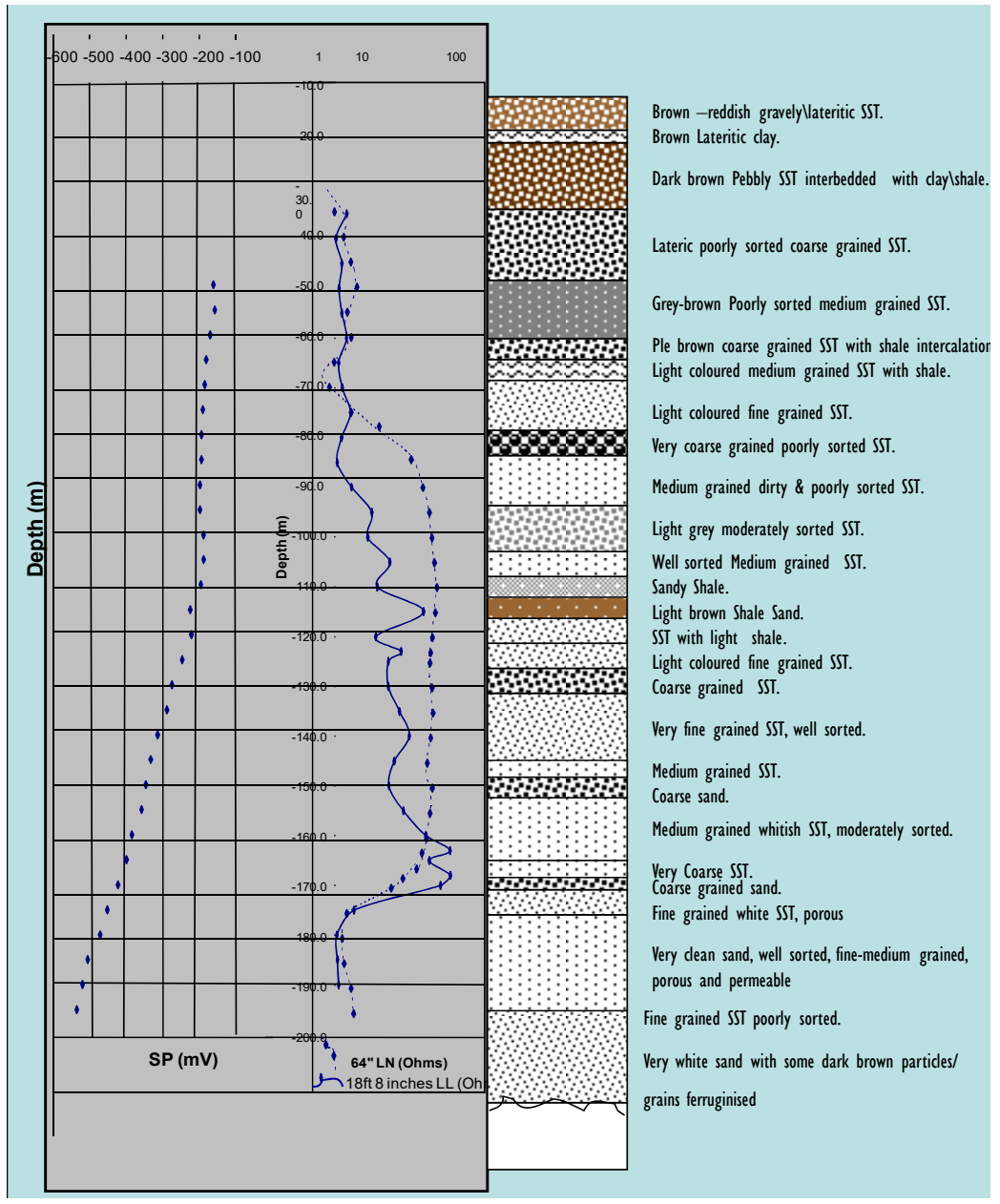

Figure 6. Log and lithological results of the borehole (Z05) at Zenith Bank, Nsukka Town 
Table 3. Calculated permeability (k), hydraulic conductivity $(\mathrm{K})$ and Transmissivity $(\mathrm{T})$ values for Ajali Sandstone Aquifer from the selected boreholes locations

\begin{tabular}{|c|c|c|c|c|c|}
\hline & Method for & & AquIfer & arameters & \\
\hline Aquifer Units & $\begin{array}{l}\text { obtaining the } \\
\text { Hydraulic } \\
\text { conductivity } \\
\text { values }\end{array}$ & $\begin{array}{l}\text { Permeability }(\mathrm{k}) \\
\left(\mathrm{cm}^{2}\right)\end{array}$ & $\left(\mathrm{m}^{2}\right)$ & $\begin{array}{l}\text { Hydraulic } \\
\text { conductivity }(\mathrm{K}) \\
\left(\mathrm{ms}^{-1}\right)\end{array}$ & $\begin{array}{l}\text { Transmissivity } \\
\text { (T) }\left(\mathrm{m}^{2} \mathrm{~s}^{-1}\right)\end{array}$ \\
\hline Abuja 2 well & Kozeny & 0.1494812 & $1.4948 \times 10^{-5}$ & 164.5973 & 10534.2300 \\
\hline Franco 3 well & Carman in Bear & 0.0790994 & $7.9099 \times 10^{-6}$ & 87.0982 & 4790.4000 \\
\hline Zenith 5 well & $\begin{array}{l}(1972) \quad \mathrm{C}= \\
64.1\end{array}$ & 0.1588398 & $1.5884 \times 10^{-5}$ & 174.9023 & 7870.6000 \\
\hline Abuja 2 well & Uma & 0.0142252 & $1.4225 \times 10^{-6}$ & 15.6640 & 1002.4770 \\
\hline Franco 3 well & (1989) & 0.0075274 & $7.5274 \times 10^{-7}$ & 8.2886 & 455.8730 \\
\hline Zenith 5 well & $\mathrm{C}=6.1$ & 0.0151158 & $1.5116 \times 10^{-6}$ & 16.6444 & 748.9964 \\
\hline
\end{tabular}

Note 1 . Hydraulic conductivity $(\mathrm{K})=\mathrm{k} \delta \mathrm{g} / \mu$

Where $\mathrm{k}=$ permeability $\delta=$ Density of water $=\{1000 \mathrm{~kg} / \mathrm{m} 3\} ; \mathrm{g}=$ Earth's gravitational acceleration $=\{9.8 \mathrm{~m} / \mathrm{s} 2\}$;

$\mu=$ Viscosity of water $=\{0.00089 \mathrm{Newton} . \mathrm{Sec} / \mathrm{m} 2 \mathrm{Bolz}$ and Tuve $(1973)\}$

Note 2. Transmissivity $(\mathrm{T})=\mathrm{Kb}$, Where $\mathrm{K}=$ Hydraulic conductivity; $\mathrm{b}=$ Aquifer thickness

The borehole results were utilized to produce water level in different locations as presented in Tables 4 and 5; Figure 7).

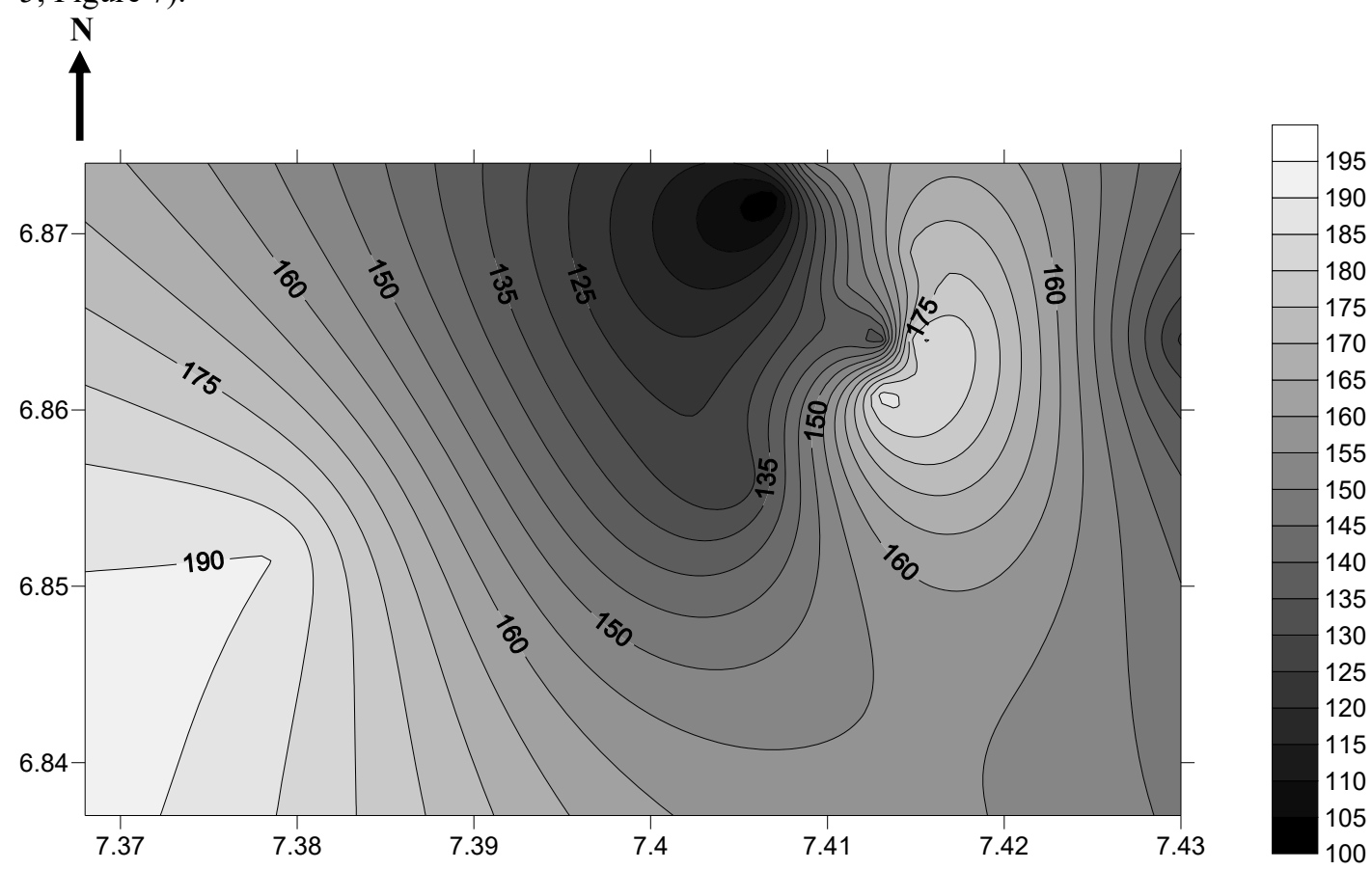

Figure 7. Isopach map of the aquiferous layer(s) 
Table 4. Water level in different locations of the study area

\begin{tabular}{|c|c|c|c|c|c|c|c|c|c|}
\hline \multirow[t]{2}{*}{ S/No. } & \multirow[t]{2}{*}{ Location } & \multirow[t]{2}{*}{$\begin{array}{l}\text { Lat } \\
(X) \\
O_{N}\end{array}$} & \multirow[t]{2}{*}{$\begin{array}{l}\text { Long } \\
(Y) \\
{ }^{o}\end{array}$} & \multirow[t]{2}{*}{$\begin{array}{l}\text { Elevation } \\
(\mathrm{m})\end{array}$} & \multirow[t]{2}{*}{$\begin{array}{l}\text { Depth } \\
\text { to } \\
\text { Water } \\
\text { Table } \\
\text { (m) }\end{array}$} & \multirow[t]{2}{*}{$\begin{array}{l}\text { Depth to } \\
\text { groundwater } \\
\text { from well log } \\
\text { data }(\mathrm{m})\end{array}$} & \multirow[t]{2}{*}{$\begin{array}{l}\text { Range of Depth } \\
\text { to groundwater } \\
\text { from Sounding } \\
\text { results }(m)\end{array}$} & \multicolumn{2}{|c|}{$\begin{array}{l}\text { Depth to } \\
\text { groundwater from } \\
\text { Sounding results } \\
\text { (Mid/Average } \\
\text { value) } \\
\end{array}$} \\
\hline & & & & & & & & $\begin{array}{l}\text { In } \\
\text { meters }\end{array}$ & In feet \\
\hline 1. & UNN-BH & 6.869 & 7.415 & 402.9 & 14 & & $145-200$ & 172.5 & 565.94 \\
\hline 2. & ABUJA-BH & 6.867 & 7.411 & 421.5 & 10 & $\begin{array}{l}132 \\
(\mathrm{SWL}=145)\end{array}$ & $135-155$ & 145 & 475.72 \\
\hline 3. & ENERGY CTR. & 6.868 & 7.413 & 424.2 & 18 & $\begin{array}{l}145 \\
(\mathrm{SWL}=148)\end{array}$ & $145-165$ & 155 & 508.53 \\
\hline 4. & $\begin{array}{l}\text { AWOLOWO } \\
\text { HALL }\end{array}$ & 6.864 & 7.413 & 445.6 & 17 & & $85-175$ & 130 & 426.51 \\
\hline 5. & UBA & 6.864 & 7.415 & 455.3 & 18 & & $180-190$ & 185 & 606.96 \\
\hline 6. & $\begin{array}{l}\text { AKPABIO } \\
\text { HALL }\end{array}$ & 6.862 & 7.415 & 448.0 & 26 & & $180-180$ & 180 & 590.55 \\
\hline 7. & $\begin{array}{l}\text { MEDICAL } \\
\text { CTR. }\end{array}$ & 6.861 & 7.413 & 456.8 & 29 & & $180-195$ & 187.5 & 615.16 \\
\hline 8. & ODENIGWE & 6.856 & 7.405 & 460.3 & 33 & & $120-130$ & 125 & 410.10 \\
\hline 9. & FRANCO-BH & 6.867 & 7.407 & 412.1 & 6 & $\begin{array}{l}125 \\
(\mathrm{SWL}=135)\end{array}$ & $80-120$ & 100 & 328.08 \\
\hline 10. & ORBA AREA & 6.863 & 7.424 & 448.6 & 21 & & $100-128$ & 114 & 406.82 \\
\hline 11. & ODIM AREA & 6.874 & 7.409 & 410.2 & 28 & & $140-160$ & 150 & 492.13 \\
\hline 12. & OBUKPA RD. & 6.881 & 7.399 & 382.5 & 18 & & $110-130$ & 120 & 393.70 \\
\hline 13. & $\begin{array}{l}\text { OBUKPA } \\
\text { L/OUT }\end{array}$ & 6.879 & 7.397 & 385.2 & 13 & & $80-120$ & 100 & 328.08 \\
\hline 14. & ZENITH BANK & 6.852 & 7.395 & 454.1 & 35 & $\begin{array}{l}165 \\
(\mathrm{SWL}=175)\end{array}$ & & & \\
\hline 15. & $\begin{array}{l}\text { NEW } \\
\text { ANGLICANRD }\end{array}$ & 6.837 & 7.368 & 456.5 & 45 & 175 & & & \\
\hline $\begin{array}{l}16 . \\
17 .\end{array}$ & $\begin{array}{l}\text { OFULONU RD. } \\
\text { EDE-OBALLA }\end{array}$ & $\begin{array}{l}6.852 \\
6.811\end{array}$ & $\begin{array}{l}7.379 \\
7.447\end{array}$ & $\begin{array}{r}453.1 \\
457.4\end{array}$ & $\begin{array}{l}45 \\
20\end{array}$ & 170 & $120-130$ & 125 & 410.10 \\
\hline
\end{tabular}

Table 5. Results of the thickness of the aquiferous layers and aquifer yield in selected locations of the study area

\begin{tabular}{|c|c|c|c|c|c|c|c|c|c|c|c|}
\hline \multirow[t]{2}{*}{ S/No. } & \multirow[t]{2}{*}{ Location } & \multicolumn{4}{|c|}{ Sounding results } & \multicolumn{6}{|c|}{ Information from Borehole log results } \\
\hline & & $\begin{array}{l}\text { Average } \\
\text { thickness } \\
\mathrm{b}(\mathrm{m})\end{array}$ & $\begin{array}{l}\text { Resistivity } \\
\rho \text { (ohm-m) }\end{array}$ & $\begin{array}{l}\text { Average } \\
\text { Long. } \\
\text { Conductance } \\
\text { S (Siemens) }\end{array}$ & $\begin{array}{l}\text { Trans. } \\
\text { Resistance } \\
\mathrm{T} \\
\left(\mathrm{Ohmm}^{2}\right)\end{array}$ & $\begin{array}{l}\text { Layer depths } \\
\text { Range h or } \\
\mathrm{z}(\mathrm{m}) / \text { Aquifer } \\
\text { Thickness } \\
\text { (m) }\end{array}$ & $\begin{array}{l}\text { True } \\
\text { Formation } \\
\text { Resistivity } \\
\text { average } \\
\left(\rho_{\mathrm{T}} \text { or } \rho_{\mathrm{i}}-\right. \\
\Omega \mathrm{m})\end{array}$ & $\begin{array}{l}\text { Average } \\
\text { Long. } \\
\text { Conductance } \\
\text { S (Siemens) }\end{array}$ & $\begin{array}{l}\text { Average } \\
\text { Trans. } \\
\text { Resistance } \\
\mathrm{T}\left(\mathrm{Ohmm}^{2}\right)\end{array}$ & $\begin{array}{l}\text { Ave. } \\
\text { Water } \\
\text { Resistivity } \\
\left(\rho_{w}-\Omega m\right)\end{array}$ & $\begin{array}{l}\text { Aquifer } \\
\text { Storage/Unit } \\
\text { Vol. OR } \\
\text { Yield OR } \\
\text { Vol. of } \mathrm{H}_{2} \mathrm{O} \\
(\mathrm{dW}) \mathrm{m}^{3}\end{array}$ \\
\hline 1. & $\begin{array}{l}\text { ABUJA- } \\
\text { BH A02 }\end{array}$ & 90.34 & 1677.15 & $\begin{array}{l}0.0011 \\
0.045989 \\
\text { Average } \Delta \mathrm{S}= \\
0.023545\end{array}$ & $\begin{array}{l}12502.6 \\
151432.8\end{array}$ & $\begin{array}{l}132-196 \\
\Delta \mathrm{h}=64\end{array}$ & 1346.31 & 0.123590 & 220726.52 & 134.634 & 4.755 \\
\hline 2. & $\begin{array}{l}\text { FRANCO- } \\
\text { BH F03 }\end{array}$ & 71.22 & 1257.80 & $\begin{array}{l}0.01852 \\
0.00351 \\
\text { Average } \Delta S= \\
0.011015\end{array}$ & $\begin{array}{l}5210.2 \\
1133.0\end{array}$ & $\begin{array}{l}125-180 \\
\Delta \mathrm{h}=55\end{array}$ & 1850.05 & 0.084413 & 285055.20 & 185.01 & 3.057 \\
\hline 3. & $\begin{array}{l}\text { ENERGY } \\
\text { CTR.- BH } \\
\text { E04 }\end{array}$ & 113.1 & 2689.10 & $\begin{array}{l}0.00641 \\
0.00521 \\
\text { Average } \Delta S= \\
0.0581\end{array}$ & $\begin{array}{l}60002.1 \\
109074.4\end{array}$ & $\begin{array}{l}148-204 \\
\Delta \mathrm{h}=56\end{array}$ & 2692.28 & 0.065960 & 473719.41 & 269.23 & 2.346 \\
\hline 4. * & $\begin{array}{l}\text { ZENITH } \\
\text { BANK- } \\
\text { BH Z05 }\end{array}$ & & & & & $\begin{array}{l}150-195 \\
\Delta \mathrm{h}=45\end{array}$ & 2409.17 & 0.625668 & 3924324.50 & 240.92 & \\
\hline
\end{tabular}

No good sounding work done in built up location(s)

Note: $\rho \mathrm{w}=\rho \mathrm{T} / \mathrm{F} ; \mathrm{dW}=1.5 \times \Delta \mathrm{S} \times \rho \mathrm{w}$. Where $\mathrm{F}=$ Formation factor $\sim 10$

3.2 VES, Borehole and Aquifer parameters

The objective of a well planned borehole geophysical survey was to obtain more information from a well than can be obtained from drilling, sampling and testing. The interpretations of the VES were from analyses of curve matching and the Parameters and functions of Dar Zarrouk (Habberjam and Watkins, 1967; Henriet, 1976; Mamah, 1998; Mamah and Ekinne, 1989).

Most of the sounding curves including VES: UNN, ABUJA, ENERGY CENTRE, MEDICAL CENTRE, FRANCO BH-I, EDE-OBALLA-I are a four-layer HA type section while sounding curve VES: AWOLOWO II, and OBUKPA ROAD I, are a three-layer HA-type section. VES: ABUJA I, AWOLOWO I, UBA, AKPABIO, 
ODENIGWE, FRANCO BH-II, ODIM, OBUKPA LAYOUT I, are a five-layer HA-type section while only OBUKPA ROAD II AND OBUKPA LAYOUT II are a 6 layer A-type section. The lithologic information from a producing borehole (A02) in conjunction with the geology of the area was utilized in constructing the various earth models.

Generally the sounding curves indicate a high resistivity ( $>1000 \mathrm{ohm}-\mathrm{m})$ for the top weathered lateritic layer of varying thickness and dryness. Most of the VES including: ABUJA I and II, ENERGY CENTRE I and II, FRANCO I and II, and OBUKPA I and II, penetrated Ajali Sandstone at a depth of at least 30m (see Tables 4 and 5). Apart from VES FRANCO I and II, the maximum current electrode spacing used was $1000 \mathrm{~m}$, the rising part of the resistivity curves are not well developed to enable the resistivity of the basal rock unit to be determined.

In most of the VES results, the third layer have high resistivity ( $>5000 \mathrm{ohm}-\mathrm{m})$ and are probably sandstonebearing freshwater zone. In all the sounding curves, this layer/zone is overlain by a low resistivity layer (200$500 \mathrm{ohm}-\mathrm{m}$ ) which was interpreted as clay. A freshwater aquifer thickness of about $100 \mathrm{~m}$ is indicated in most of the sounding curves/results, while in others ones, the rising nature of the resistivity curves makes it difficult to determine the thickness of the freshwater zone. However, since at the same current electrode spacing the shale bed (Mamu Formation) is yet to be penetrated along all the sounding curves it follows that from the point of view of groundwater potential, the neighbourhood of this sounding point may be the most promising. Table 4 shows the results of water level in different locations of the study area.

It should be noted that, practically, there are often erratic variations in field sounding measurements of $\rho_{\mathrm{a}}$ due to local resistivity changes near surface and poor electrode contacts. In addition, anisotropic ground and terrain effects will lead to errors in estimating both $\mathrm{h}$ and $\rho_{1}$

\subsection{Hydrogeology and Hydrology}

During rainy season, the water table rises, and as the frequency of the rainfall increases and the soil becomes increasingly saturated, the amount of infiltrations into the dynamic groundwater system increases. The run-off is significantly very low at most of the parts of the study area because of the high permeability of underlying formations. There is more or less no surface water in Nsukka area hence, little or no drainage network but there are several springs issuing from the flanks of the ridges of the several hills. Most parts are underlain by porous and permeable sandy units and so are devoid of any surface water bodies, due to the absence of intervening shale layers for infiltrating rainwater, and the

Conversely, few ephemeral springs arise from the interception of few sand lenses (perched aquifers) that exist in the areas dominated by shales and laterites of the Nsukka Formation. However, these springs do not produce enough water to meet the demand of the inhabitants.

The shortage of water, despite the high annual rainfall, about $167.5 \mathrm{~cm} / \mathrm{yr}$, therefore presents a problem in the area. Uma et al. (1989) noted that this water deficiency results from the combination of two factors as the prolonged dry season and the high permeability of the strata which allows the rainwater to infiltrate to great depth.

\section{Limitations of the geophysical surveys}

With respect to accessibility, the sounding stations were hampered by non-motorable/ winding roads that strongly threatened the straight course of the cross array sounding work. In conducting an electrical resistivity survey, the voltages are relayed to the receiver over long wires that are grounded at each end. These wires act as an antenna receiving the radiated electrical noise that in turn degrades the quality of the measured voltages. The major problem in resistivity sounding is caused by the spurious effects of near-surface lateral resistivity variations. This effect was ameliorated by measuring earth resistances at two electrode array positions such that in one position the lateral effect was a positive contribution to the total measured signal and in the other, the contribution was negative. The subsequent combination of the two measurements virtually eliminates the lateral effect. Also, Equipment errors such as: obstruction in the electrode and improper current flow, were among the factors that affected the sounding work in the study area.

\section{Conclusions}

This study has provided insight into the groundwater potentials of a portion of the Nsukka area, where hitherto, several sunk boreholes proved abortive. Geophysical surveys carried in this research indicated that the aquifer systems occur as perched and confined aquifers. Previous works on the geology of the Nsukka area, such as Akudinobi, and Egboka (1996), Nwankwor et al. (1988) and Onwuemesi, 1990) have shown that most of the lithological logs have lateritic caps varying in thickness form $10 \mathrm{~m}$ to $95 \mathrm{~m}$. Hence, boreholes that penetrated only to this depth range would yield poorly (some of the boreholes records clearly indicated a multi-aquifer system separated by clayey or sandy-clayey aquitards) or out rightly yield not water to the boreholes. This layer's lithology conforms to the literature description of the Nsukka Formation. 
Boreholes that were struck the Ajali Sanstone recorded depths of penetration of between $120 \mathrm{~m}$ and $220 \mathrm{~m}$. Most of these were terminated in sandy layers. Deeper drilling would have encountered more aquiferous horizons, and reduce the present under utilization of the aquifers. All the wells drilled as at the time of the study were screened at a section of one aquifer. It would be more advisable to screen two or more aquifers and tap all of them in a coupled manner to provide a better well-yield from the aquifer system.

Electrical resistivity survey on the top of basal Nsukka Formation was found to be poorly conductive because of tortuous current flow in the weathered vesicular laterite. The variations in the resistivities of the top layers are dependent on the moisture content, with resistivity contrast being high on drier days; parameters like: permeability $(\mathrm{k})$, hydraulic conductivity $(\mathrm{K})$, transmissivity $(\mathrm{T})$, and Specific yield have high values in most parts. This has inferred that the area has thick and prolific aquiferous zone of the Ajali Sandstone.

\section{References}

Agagu, O. K., Fayose, E. A. \& Petters, S. W. (1985), Stratigraphy and Sedimentation in the Senonian Anambra Basin of Southeastern Nigeria: Nig. Journal of Mining. Geol, 22(1 and 2):25-35.

Akudinobi, B. E. B., \& Egboka, B. C. E. (1996) Aspects of Hydrogeological Studies of the Escarpment Regions of Southeastern Nigeria: Water Resources J. NAH., 7(1 and 2):12-25.

Amajor, L. C. (1984), Sedimentary Facies Analysis of the Ajali Sandstone (Upper Creataceous), Southern Benue Trough: Nigerian. Journal of Mining Geol., 21(1 and 2):171-176.

Banerjee, I. (1979), Analysis of Cross bedded Sequences: An example from the Ajali Sandstone (Maastrichtian) of Nigeria. Quarterly Journal Geol. Min. Metal Soc. India, 51(2):69-81.

Benkhelil, J. (1987), The Origin and Evolution of Cretaceous Benue and Biostratigraphy of the Benue Trough Nigeria: Geol. Sol. America Bull., 89:151-154.

Burke, K. C., Dessauvagie, R. F. J. \& Whiteman, A. J. (1972), Geologic History of the Benue Valley and Adjacent Areas: In African Geology, University of Ibadan Press, 14-184.

Ezim, E. O., Obiadi, I. I \& Akaegbobi, M. I. (2017), The use of Statistical Grain-Size Method in Analysing Borehole and Evaluating Aquifer Parameters. A Case Study of Ajali Sandstone Formation, Southeastern Nigeria, Global Journal of Geological Sciences, 15(1):77-92, DOI: http://dx.doi.org/10.4314/gjgs.v15i1.7; www.globaljournalseries.com

Habberjam, G. M., \& Watkins, G. E. (1967), Square Configuration in Resistivity Prospecting: Geophysical Prospecting, 15:455-469.

Harleman, D. R. E., Melhorn, P. F., \& Rumer, R. R. (1963), Dispersion-Permeability Correlation in Porous Media: Jour. Hydraul. Div. American Soc. Civil Eng., HY2, 89:67-85.

Hazen, A. (1983), Some Physical Properties of Sands and Gravels, with Special Reference to their Use in Filtration: $24^{\text {th }}$ Annual Report, Massachusetts State Board of Health, Pub., Document No. 34:539-556.

Henriet, J. P. (1976), Direct Application of the Dar Zarrouk Parameters in Ground Water Surveys: Geophysical Prospecting, 24(2):344-353.

Kogbe, C. A. (1989b), The Cretaceous and Palaeogene Sediments of Southern Nigeria, In: Kogbe, C. A., (Editor): The Geology of Nigeria: Rock View Publishers, Nigeria, Lagos, 325-334.

Mamah, L. I. (1998), Uncertainty in Geosounding Interpretation: Jour. Min. Geol., 34(1):37-42.

Mamah, L. I., \& Ekinne, A. S. (1989), Electrical Resistivity Anisotropy as Indicator of Sedimentary Fabric Resulting from Tectonic Adjustments in Basal Nsukka Formation, Southeastern Nigeria: Jour. Min. Geol., 25(1 and 2):31-37.

Murat, R. C. (1972), Stratigraphy and Palaeogeography of the Cretaceous and Lower Tertiary in Southern Nigeria. In: Dessauvagie, T. F. J., Whiteman, A. J. (Eds.), African Geology. University of Ibadan Press, Nigeria, 251-266.

Nwajide, C. S. (2006a), Anambra Basin of Nigeria: Synoptic Basin Analysis as a Basis for Evaluating its Hydrocarbon Prospectively. In: Okogbue, C. O. (Ed.), Hydrocarbon Potentials of the Anambra Basin: Geology, Geochemistry and Geohistory Perspectives. Proceedings of the First Seminar Organized by the Petroleum Technology Development Fund (PTDF) Chair in Geology, University of Nigeria, Nsukka, May $12-15,2005,1-46$.

Nwajide, C. S. (2006b), A Guide for Geological Field Trips to Anambra and Related Sedimentary Basins in South Eastern Nigeria: Great AP Express Pub. L.T.D., Nsukka, 28-32.

Nwajide, C. S., \& Reijers, T. J. A. (1996), Geology of the Southern Anambra Basin; In: T.J.A. Reijers (Editor), 133-148. Selected chapters on Geology, SPDC Warri, 197P.

Nwankwor, G. I., Egboka, B. C. E., \& Orajaka, I. P. (1988), Groundwater Occurrence and Flow Pattern in the Enugu Coal-Mine Area, Anambra State, Nigeria; Hyrological Sciences-Journal-des Sciences Hydrologiques, 33(5):465-482.

Onwuemesi, A. G. (1990), Hydrogeophysical and Geotechnical Investigation of the Ajali Sandstone in Nsukka and Environs with Reference to Groundwater Resources and Gully Erosion Problems: Water Resources J. 
NAH., 2(1):70-76.

Telford, W. M., Geldart, L. P., \& Sheriff, R. E. (1990), Applied Geophysics; Cambridge University Press, 302 334.

Uma, K. O., Egboka, B. C. E., \& Onuoha, K. M. (1989), New Statistical Grain-Size Method for Evaluating the Hydraulic Conductivity of Sandy Aquifers: Journal of Hydrology, Amsterdam, 16:108, 367-386.

Acknowledgements

The authors acknowledge the assistance of Mr. Emeka Ugwu, Ifeoma Esiobu and Ifeanyi Obi, during the fieldwork and data collection. Mr. Godwin Alo of the Geological survey of Nigeria assisted in the processing of the VES data. Professor Onwuemesi (Geology, NAU Awka), Dr. Okechukwu Aghamelu and Dr. Amobi Ekwe (Earth Sciences, AEFUNAI) Nigeria, proof-read the initial draft of the manuscript. They are warmly appreciated.

Postal address of the corresponding author: C/O Dr. (Mrs.) Ogechukwu E. Ezim, Department of Biochemistry (Faculty of Science), University of Port Harcourt, Choba/Port Harcourt Rivers State, Nigeria

Tel: +234 0 8030722355; the research was financed by the author 